\title{
Correlations of complete blood count, liver enzyme and serum uric Acid in Sudanese pre-eclamptic cases
}

\author{
Hind M. Beheiry ${ }^{1 *}$, Ibrahim A. Ali², Mazin S. Abdalla ${ }^{3}$, Ahmed M. Sharif ${ }^{4}$, Amal M. Saeed \\ ${ }^{1}$ Department of Physiology, Faculty of Medicine, International University of Africa, Khartoum, Sudan \\ ${ }^{2}$ Department of Physiology, Faculty of Medicine, The National Ribat University, Khartoum, Sudan \\ ${ }^{3}$ Department of physiology, Faculty of Medicine, Napata College, Khartoum, Sudan \\ ${ }^{4}$ Department of Medicine, Faculty of Medicine, University of Khartoum, Khartoum, Sudan
}

Received: 17 January 2018

Accepted: 28 February 2018

\section{*Correspondence:}

Dr. Hind Beheiry,

E-mail: hindbeheiry@hotmail.com

Copyright: $\odot$ the author(s), publisher and licensee Medip Academy. This is an open-access article distributed under the terms of the Creative Commons Attribution Non-Commercial License, which permits unrestricted non-commercial use, distribution, and reproduction in any medium, provided the original work is properly cited.

\begin{abstract}
Background: Pre-eclampsia is a serious disorder of pregnancy with unknown ethological factors that may occur at any stage of second or third trimester of pregnancy. The objectives of the present study were to assess changes in complete blood counts including platelets, liver enzymes and serum uric acid in pre-eclamptic cases compared to second-half normal pregnant and non-pregnant Sudanese women and their correlations to other biomarkers.

Methods: This was a cross-sectional, case-control study performed from December 2008 to December 2010; in Omdurman Maternity Hospital, in concomitance with other studies in pre-eclampsia. The sample size included three groups, 72 up pre-eclamptic cases in their recent pregnancies, 96 normal pregnant in their second half of pregnancy and 63 non- pregnant (control) women; a total of 231 subjects. Questionnaire Interviews and clinical examination were done for all participants. Laboratory investigations were done including complete blood picture, liver enzymes and uric acid.

Results: The mean $\mathrm{Hb}$ concentration of the pre-eclamptic $(11.3 \mathrm{~g} / \mathrm{dl} \pm 1.7)$ was statistically significantly lower than that of the non-pregnant $(12.1 \mathrm{~g} / \mathrm{d} 1 \pm 0.2)(\mathrm{P}=0.01)$ but not from that of the normal pregnant $(11.4 \mathrm{~g} / \mathrm{dl} \pm 0.1)(\mathrm{P}=0.882)$. There was no statistical significant difference in the mean WBC count between the pre-eclamptic $(7.4 \times 103 / \mathrm{mm} 3 \pm 0.3)$ and non-pregnant $(7.3 \times 103 / \mathrm{mm} 3 \pm 0.3)(\mathrm{P}=0.797)$ and between the pre-eclamptic and normal pregnant $(7.7 \times 103 / \mathrm{mm} 3 \pm 0.2)$ $(\mathrm{P}=0.270)$. There was a considerable statistical significant decrease in the mean platelets count of the pre-eclamptic $(236.4 / \mathrm{mm} 3 \pm 8.3)$ compared to the non-pregnant group $(322.0 / \mathrm{mm} 3 \pm 10.4)(\mathrm{P}=0.0001) \mathrm{s}$ well as to the normal pregnant $(275.0 / \mathrm{mm} 3 \pm 8.9)(\mathrm{P}=0.003)$. In the pre-eclamptic cases, serum ALT correlated significantly with TWCC $(\mathrm{r}=0.26, \mathrm{P}=0.03)$ and serum AST $(\mathrm{r}=0.65, \mathrm{P}=0.000)$. In the pre-eclamptic cases, serum AST correlated significantly with $\mathrm{Hb}(\mathrm{r}=0.26, \mathrm{P}=0.03)$, serum ALT and serum uric acid $(\mathrm{r}=0.36, \mathrm{P}=0.01)$.

Conclusions: There was a considerable statistical significant decrease in mean platelets count of the pre-eclamptic compared to the non-pregnant group and to the normal pregnant may be explained by hemodilution; whereas further decrease was due to pre-eclampsia. ALT and AST are strong prognostic indicators of pre-eclampsia.
\end{abstract}

Keywords: ALT, AST, CBC, Liver enzymes, Pre-eclampsia

\section{INTRODUCTION}

Pre-eclampsia is a diverse, multi-organ group of related disease processes. Pre-eclampsia occurs in 5\%-8\% of pregnancies after 20 weeks of gestation. The presentation is highly variable; but generally, includes the combination of maternal hypertension and proteinuria.

Pre-eclampsia is described as a new onset of hypertension (SBP $\geq 140 \mathrm{~mm}$ of $\mathrm{Hg}$ or $\mathrm{DBP} \geq 90 \mathrm{~mm}$ of $\mathrm{Hg}$ ) and 
proteinuria $(\geq 0.3 \mathrm{~g}$ or $300 \mathrm{mg}$ protein in a 24 -hour urine specimen or $1+$ on dipstick) after 20 weeks of gestational age; it's also referred to as toxaemia of pregnancy. ${ }^{1}$ Severe pre-eclampsia is associated with pitting edema, headache, visual disturbances, and epigastric pain after $20^{\text {th }}$ week gestation. ${ }^{2,3}$ Pre-eclampsia is a leading cause of maternal and fetal morbidity and mortality in developing countries. ${ }^{4.5}$ The targeted organs are kidney, liver and brain which could be attributed to auto-intoxication; physiological derangement of the organs is self-evident. ${ }^{6}$ Reduction in utero-placental perfusion is considered as a major cause of fetal distress in pre-eclampsia.,

Pre-eclampsia is a disorder in which a multitude of environmental, genetic as well as immunological factors intersect. ${ }^{9}$ There are several studies which suggested that platelets may play a major role in the etiopathogenesis of pre-eclampsia. Changes in coagulation system, in established pre-eclampsia, are well documented. ${ }^{10}$

Among the hematological changes that occur in preeclampsia, thrombocytopenia is the most common. Thrombocytopenia is classically defined as a platelet count less than $150,000 / \mathrm{cu} \mathrm{mm} .{ }^{11}$ The pathogenesis of thrombocytopenia in pre-eclampsia is not clear. Although it is suggested that low platelet count in pre-eclampsia are associated with abnormal activation of coagulation system and accelerated platelet consumption. ${ }^{12}$

Severe pre-eclampsia has been characterized by one or more of the following criteria: sustained systolic BP 160 $\mathrm{mmHg}$ or diastolic BP $110 \mathrm{mmHg}$ while on bed rest, nephrotic-range proteinuria, sudden oliguria, central nervous system disturbances, pulmonary edema or cyanosis, epigastric or right upper quadrant pain, liver dysfunction, thrombocytopenia, and fetal growth restriction. $^{13,14}$

Thus, severe pre-eclampsia may be diagnosed even with mildly elevated BP if there is other evidence of significant end organ disease. HELLP syndrome may or may not occur in conjunction with proteinuria or hypertension, although most patients will also have preeclamptic symptoms. ${ }^{15,16}$ HELLP syndrome is considered to be a severe form of disease, so its management may include prompt delivery of the fetus whether or not proteinuria or hypertension is present.

Uric acid (UA) has been associated for long time with pre-eclampsia, and it is of simple and inexpensive determination. Briefly, UA is the oxidation end product of purine metabolism in humans and higher primates, and its serum level results from the balance of endogenous production, dietary intake and elimination, which occurs for one-third through the gastro-enteric tract and for the remaining two-thirds through the kidney, by filtration and active secretion. Normal values in non-pregnant women of childbearing age, range from 3.0 to $6.0 \mathrm{mg} / \mathrm{dl}$, lower than in men, as estrogens have a potent uricosuric effect.
Maternal mortality due to pre-eclampsia might be reduced through regular monitoring of platelet count and serum uric acid as a part of antenatal care routine checkup. Few studies are done in this area in Sudan. Therefore, the present study was designed to assess the association of complete blood count including platelets, liver enzymes and serum uric acid in pre-eclampsia.

\section{METHODS}

This was a cross-sectional, case-control and hospitalbased study performed during a two-year period from December 2008 to December 2010; in Omdurman Maternity Hospital, in concomitance with other studies in pre-eclampsia. The objectives of the study were to assess changes in complete blood counts including platelets, liver enzymes and serum uric acid in pre-eclamptic cases compared to second-half normal pregnant and nonpregnant Sudanese women and their correlations to other biomarkers.

The samples selection was done by a systematic random selection every other day. It included three groups, 72 newly discovered and/or already diagnosed and followedup pre-eclamptic cases in their recent pregnancies, 96 normal pregnant in their second half of pregnancy (20 weeks of pregnancy and onwards) and 63 non- pregnant (control) women; a total of 231 subjects. Selected participants were informed about the study; and their written consent was taken prior to admission into the antenatal ward for one day they were assured about the privacy of the data.

\section{Inclusion criteria}

- All the pregnant participants to be in the second half of pregnancy with regular follow-up cards and all the non-pregnant to have no history of diabetes mellitus, essential hypertension, renal disease or any other chronic disease.

\section{Exclusion criteria}

- Subjects with multiple pregnancies and/or have any obstetrical abnormality like placenta praevia, polyhydramnios

The enrolment of pregnant women for the study was performed by the assigned obstetricians in the antenatal care clinics. Questionnaire Interviews and clinical examination were done for all participants. Laboratory investigations were done including complete blood picture, liver enzymes and uric acid.

\section{Statistical analysis}

The data was analyzed by SPSS software R 9.0 (SPSS, Inv., Chicago, IL, USA) program Version 20, with the use of Spearman's test, t-student, Chi-square, 
Independent sample T-test and Bivariate correlation test. $\mathrm{P} \leq 0.05$ was considered statistically significant.

\section{RESULTS}

\section{Platelets count $\left(/ \mathrm{mm}^{3}\right)$}

There was a considerable statistical significant decrease in the mean platelets count of the pre-eclamptic $\left(236.4 / \mathrm{mm}^{3} \pm 8.3\right)$ compared to the non-pregnant group $\left(322.0 / \mathrm{mm}^{3} \pm 10.4\right) \quad(\mathrm{P}=0.0001) \mathrm{s}$ well asto the normal pregnant $(275.0 / \mathrm{mm} 3 \pm 8.9)(\mathrm{P}=0.003)($ Tables 1 and 2 respectively) (Figure 1).

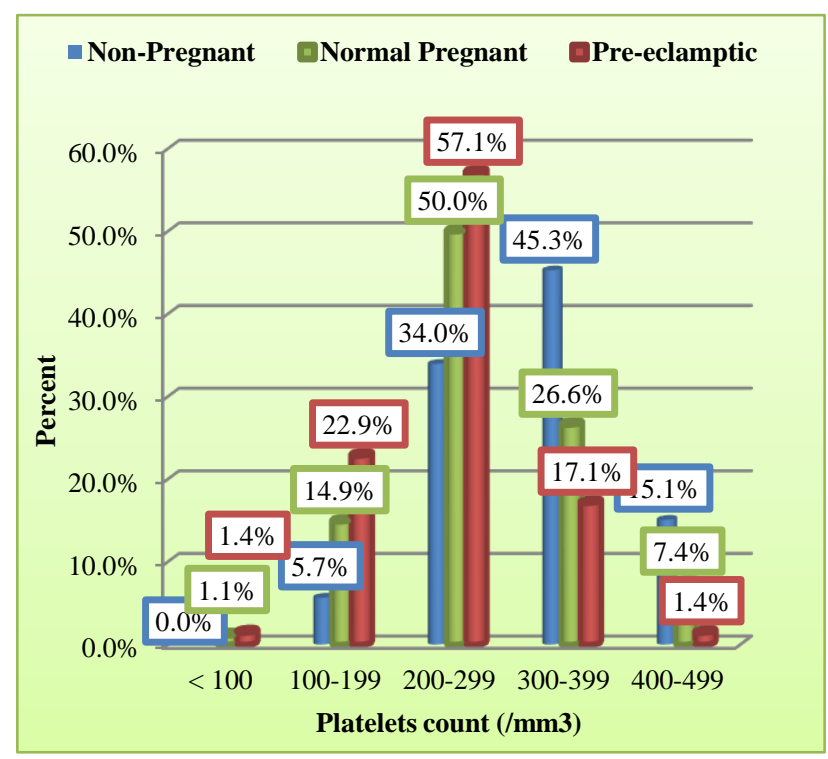

Figure 1: Histogram of platelets count $(/ \mathrm{mm} 3)$ in the three groups.

\section{Hemoglobin $(g / d l)$ levels}

The mean $\mathrm{Hb}$ concentration showed limited variation in values in the three groups. The mean $\mathrm{Hb}$ concentration of the pre-eclamptic $(11.3 \mathrm{~g} / \mathrm{dl} \pm 1.7)$ was statistically significantly lower than that of the non-pregnant $(12.1 \mathrm{~g} / \mathrm{dl} \pm 0.2)(\mathrm{P}=0.01)$ but not from that of the normal pregnant $(11.4 \mathrm{~g} / \mathrm{dl} \pm 0.1) \quad(\mathrm{P}=0.882) \quad($ Tables 1 and 2 respectively) (Figure 2 ).

Table 1: Comparisons of means between the nonpregnant and pre-eclamptic cases.

\begin{tabular}{|c|c|c|c|}
\hline \multicolumn{2}{|c|}{ Category of participant } & Mean \pm SE & $\begin{array}{l}\text { P- } \\
\text { value }\end{array}$ \\
\hline \multirow{2}{*}{ Hemoglobin } & Non-pregnant & $12.1 \pm 0.2$ & \multirow{2}{*}{$0.005^{*}$} \\
\hline & Pre-eclampsia & $11.3 \pm 1.5$ & \\
\hline \multirow{2}{*}{ Platelets } & Non-pregnant & $322.0 \pm 0.4$ & \multirow{2}{*}{0.000} \\
\hline & Pre-eclampsia & $236.4 \pm 8.3$ & \\
\hline \multirow{2}{*}{$\begin{array}{l}\text { Total WBC } \\
\text { count }\end{array}$} & Non-pregnant & $7.3 \pm 0.3$ & \multirow{2}{*}{0.797} \\
\hline & Pre-eclampsia & $7.4 \pm 0.3$ & \\
\hline
\end{tabular}

Table 2: Comparisons of means between the nonpregnant and pre-eclamptic cases.

\begin{tabular}{|c|c|c|c|}
\hline \multicolumn{2}{|c|}{ Category of participant } & Mean \pm SE & $\begin{array}{l}P \text { - } \\
\text { value }\end{array}$ \\
\hline \multirow{2}{*}{ Hemoglobin } & Pregnant & $11.4 \pm 0.1$ & \multirow{2}{*}{0.88} \\
\hline & Pre-eclampsia & $11.3 \pm 1.5$ & \\
\hline \multirow{2}{*}{ Platelets } & Pregnant & $275.0 \pm 8.9$ & \multirow{2}{*}{$0.003^{*}$} \\
\hline & Pre-eclampsia & $236.4 \pm 8.3$ & \\
\hline \multirow{3}{*}{$\begin{array}{l}\text { Total WBC } \\
\text { count }\end{array}$} & Pregnant & $7.7 \pm 0.2$ & \multirow{3}{*}{0.27} \\
\hline & Pre-eclampsia & $7.4 \pm 0.3$ & \\
\hline & Pre-eclampsia & $0.342 \pm 0.01$ & \\
\hline
\end{tabular}

$*$ P-value $(<0.05)$ is significant.

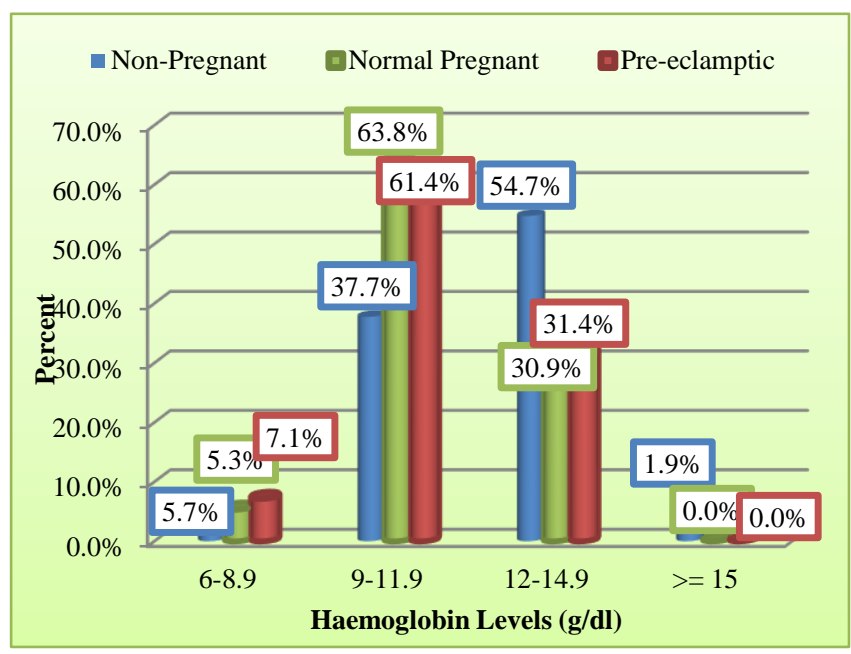

Figure 2: Histogram of hemoglobin levels (g/dl) in the three groups.

\section{White blood cells count (WBC) $\left(x 103 / \mathrm{mm}^{3}\right)$}

There was no statistical significant difference in the mean WBC count between the pre-eclamptic $(7.4 \times 103 / \mathrm{mm} 3 \pm 0.3) \quad$ and non-pregnant $(7.3 \times 103 / \mathrm{mm} 3 \pm 0.3) \quad(\mathrm{P}=0.797)$ and between the preeclamptic and normal pregnant $(7.7 \times 103 / \mathrm{mm} 3 \pm 0.2)$ $(\mathrm{P}=0.270)$ (Tables 1 and 2 respectively).

\section{Serum alanine aminotransferase (U/L) activity}

Serum ALT of the normal pregnant group correlated significantly with serum AST $(r=0.54, \mathrm{P}=0.000)$. In the pre-eclamptic cases, serum ALT correlated significantly with TWCC $(\mathrm{r}=0.26, \mathrm{P}=0.03)$ and serum AST $(\mathrm{r}=0.65$, $\mathrm{P}=0.000)$.

\section{Serum aspartate aminotransferase (U/L) activity}

Serum AST of the normal pregnant group correlated significantly with serum ALT $(r=0.25, \mathrm{P}=0.01)$. In the pre-eclamptic cases, serum AST correlated significantly with $\mathrm{Hb}(\mathrm{r}=0.26, \mathrm{P}=0.03)$, serum $\mathrm{ALT}$ and serum uric acid $(\mathrm{r}=0.36, \mathrm{P}=0.01)$. 
Table 3: The correlations between the variables and displays the $\mathbf{r}$ and the p-values for the variables in the study.

\begin{tabular}{|c|c|c|c|c|c|c|c|c|c|c|c|c|c|}
\hline Correlation & & SBP & DBP & MBP & UP & $\begin{array}{l}\text { UTP } \\
(\mathrm{gm} / \mathrm{L})\end{array}$ & $\mathrm{Hb}$ & platelets & $\begin{array}{l}\text { Total } \\
\text { WBC } \\
\text { count }\end{array}$ & $\begin{array}{l}\text { SA } \\
(\mathrm{gm} / \mathrm{L})\end{array}$ & SAT & $\begin{array}{l}\text { Serum } \\
\text { aspartate } \\
\text { transferase }\end{array}$ & $\begin{array}{l}\text { SUA } \\
(\mathrm{mmol} / \mathrm{L})\end{array}$ \\
\hline \multirow[b]{2}{*}{$\mathrm{Hb}$} & $\mathrm{CC}$ & 0.11 & -0.04 & 0.02 & -0.12 & -0.18 & 1.00 & -0.03 & -0.01 & -0.13 & 0.15 & 0.26 & 0.00 \\
\hline & $\begin{array}{l}P \\
\text { value }\end{array}$ & 0.381 & 0.728 & 0.859 & 0.325 & 0.155 & - & 0.792 & 0.942 & .0268 & 0.234 & 0.033 & 0.986 \\
\hline \multirow[b]{2}{*}{ platelets } & $\mathrm{CC}$ & 0.29 & -0.11 & -0.24 & -0.11 & -0.13 & -0.03 & 1.00 & 0.29 & 0.18 & -0.11 & -0.12 & -0.14 \\
\hline & $\begin{array}{l}\mathrm{P} \\
\text { value }\end{array}$ & 0.016 & 0.383 & 0.052 & 0.367 & 0.332 & 0.792 & - & 0.014 & 0.147 & 0.375 & 0.331 & 0.246 \\
\hline \multirow{2}{*}{$\begin{array}{l}\text { Total } \\
\text { WBC } \\
\text { count }\end{array}$} & $\mathrm{CC}$ & 0.12 & 0.08 & 0.11 & -0.14 & 0.03 & -0.01 & 0.29 & 1.00 & 0.23 & 0.26 & 0.00 & -0.07 \\
\hline & $\begin{array}{l}\mathrm{P} \\
\text { value }\end{array}$ & 0.316 & 0.495 & 0.358 & 0.256 & 0.819 & 0.942 & 0.014 & - & 0.059 & 0.034 & 0.979 & 0.535 \\
\hline \multirow[b]{2}{*}{ SAT } & $\mathrm{CC}$ & 0.06 & 0.15 & 0.10 & -0.08 & 0.13 & 0.15 & -0.11 & 0.26 & 0.31 & 1.00 & 0.65 & 0.07 \\
\hline & $\begin{array}{l}\mathrm{P} \\
\text { value }\end{array}$ & 0.639 & 0.227 & 0.429 & 0.521 & 0.307 & 0.234 & 0.375 & 0.034 & 0.009 & - & 0.00 & 0.569 \\
\hline \multirow{2}{*}{$\begin{array}{l}\text { Serum } \\
\text { aspartate } \\
\text { transferase }\end{array}$} & $\mathrm{CC}$ & 0.11 & 0.12 & 0.10 & 0.12 & 0.21 & 0.26 & -0.12 & 0.00 & 0.08 & 0.65 & 1.00 & 0.36 \\
\hline & $\begin{array}{l}\mathrm{P} \\
\text { value }\end{array}$ & $\begin{array}{l}0.36 \\
3\end{array}$ & 0.343 & 0.407 & 0.338 & 0.11 & 0.033 & 0.331 & 0.979 & 0.499 & 0.00 & - & 0.002 \\
\hline \multirow{2}{*}{$\begin{array}{l}\text { SUA } \\
(\mathrm{mmol} / \mathrm{L})\end{array}$} & $\mathrm{CC}$ & 0.16 & 0.22 & 0.22 & 0.17 & 0.29 & 0.00 & -0.14 & -0.07 & -0.49 & 0.07 & 0.36 & 1.00 \\
\hline & $\begin{array}{l}\mathrm{P} \\
\text { value }\end{array}$ & 0.191 & 0.066 & 0.072 & 0.165 & 0.023 & 0.986 & 0.246 & 0.535 & 0.00 & 0.569 & 0.002 & - \\
\hline
\end{tabular}

CC- Correlation coefficient, SBP- Systolic blood pressure, DBP- Diastolic blood pressure, MBP- Mean blood pressure, SAT-Serum alanine transferase, Hb- Hemoglobin, SUA- Serum uric acid, UTP- Urine total protein, SA- Serum albumin, UP- Urine protein

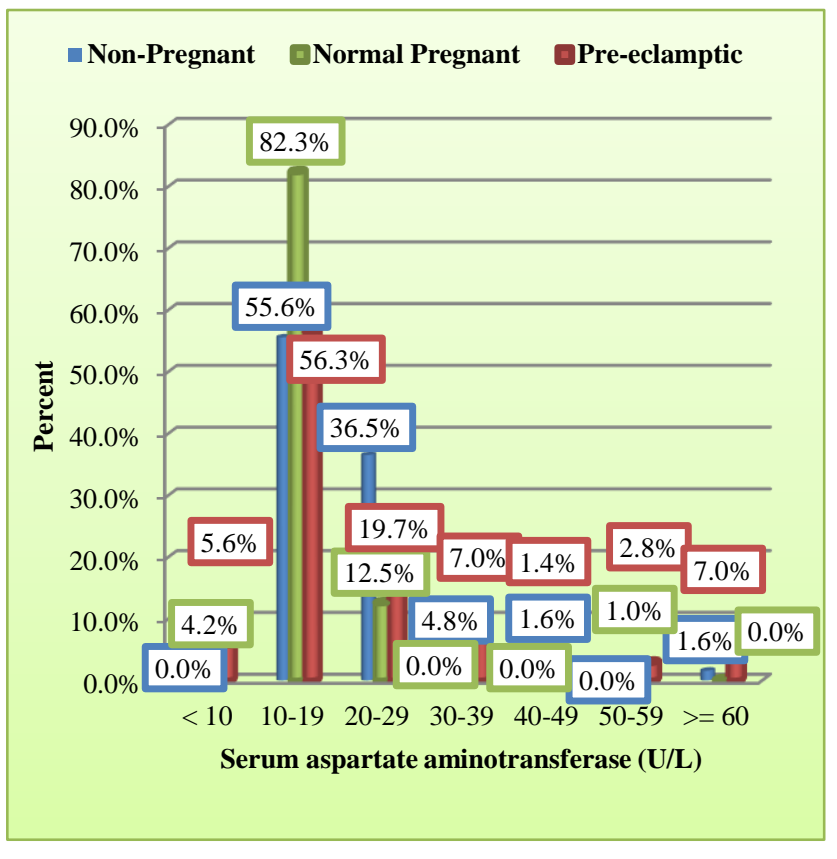

Figure 3: Histogram of liver transaminase AST (U/L) in the three groups.

The correlation coefficient between the hemoglobin and the serum uric acid was 0.00 which signifies no correlation between the two variables. On the other hand, statistical significance between the following variables was observed. Platelets and systolic blood pressure ( $p$ 0.016); uric acid and serum albumin (p-0.000); uric acid and AST (p-0.002) and AST and hemoglobin (0.033).
In reference to the earlier publication which investigated Cystatin $\mathrm{C}$ as a better indicator of the glomerular filtration rate, which concluded that, an increment in the levels of Cystatin $\mathrm{C}$ correlated positively with pregnancy and more so with pre-eclampsia. Cystatin $\mathrm{C}$ concentrations also were observed to correlate negatively with the serum album and positively with serum aspartate aminotransferase with significance. Serum cystatin C correlated with serum albumin $(\mathrm{r}=-0.41, \mathrm{P}=0.0001)$, serum aspartate aminotransferase $(\mathrm{r}=0.26, \mathrm{P}=0.03)$ and serum uric acid $(\mathrm{r}=0.60, \mathrm{P}=0.0001)$ in the pre-eclamptic group.

\section{DISCUSSION}

Pre-eclampsia is a serious disorder of pregnancy with unknown ethological factors that may occur at any stage of second or third trimester of pregnancy. ${ }^{17,18}$

There was a considerable statistical significant decrease in mean platelets count of the pre-eclamptic (236.4 / $\mathrm{mm} 3 \pm 8.3$ ) compared to the non-pregnant group $(322.0 / \mathrm{mm} 3 \pm 10.4) \quad(\mathrm{P}=0.0001)$ and to the normal pregnant $(275.0 / \mathrm{mm} 3 \pm 8.9)(\mathrm{P}=0.003)$; this may be explained by hemodilution; whereas further decrease was due to pre-eclampsia. ${ }^{19}$

The mean $\mathrm{Hb}$ concentration showed limited variation in values in the three groups. The mean $\mathrm{Hb}$ concentration of the pre-eclamptic $(11.3 \mathrm{~g} / \mathrm{dl} \pm 1.7)$ was statistically significantly lower than that of the non-pregnant $(12.1 \mathrm{~g} / \mathrm{dl} \pm 0.2)(\mathrm{P}=0.01)$ but not than from that of the normal pregnant $(11.4 \mathrm{~g} / \mathrm{dl} \pm 0.1)(\mathrm{P}=0.882)$ this could be attributed to hemodilution in normal pregnancy. 
In pre-eclampsia, the liver function tests are affected and are known signs of deterioration of the condition. ALT and AST are strong prognostic indicators of preeclampsia. The increment in their levels may indicate deterioration of the condition. ${ }^{20}$ In this study, both ALT and AST increased in the pre-eclamptic cases when compared to normal pregnant women. ${ }^{21}$

\section{CONCLUSION}

This study revealed that further investigation of the relation between platelets dysfunction and preeclampsia needed to be done in the future and a question about the use of hematological profile as a screening program for pregnant ladies with obvious risk factors of preeclampsia or pregnancy induced hypertension(PIH) should be answered.

\section{ACKNOWLEDGMENTS}

Author were highly grateful to all those who volunteered to donate their blood when needed for this project.

\section{Funding: No funding sources}

Conflict of interest: None declared

Ethical approval: Ethical approval was approved by the Research Committee (Faculty of Medicine, IUA). Permission was given from Omdurman Maternal Hospital to conduct the study for cases of pre-eclampsia and normal pregnant subjects.

\section{REFERENCES}

1. Mashiloane CD, Moodley J. Induction or Caesarean section for pre-term preeclampsia. J Obstet Gynecol. 2002;22(4):353-6.

2. American College of Obstetricians and Gynecologists. Diagnosis and management of preeclampsia and eclampsia. ACOG Practice Bulletin No.33. Obstet Gynecol. 2002;99:159-67. (Level III)

3. Reports of the National High Blood Pressure Education Program Working Group report on high blood pressure in Pregnancy. Am J Obstet Gynecol. 2000;183:S1-S22.

4. Cunningham FG, Leveno KJ, Bloom SL, Hauth JC, Rouse DJ, Spong CY. Williams Obstetrics $23^{\text {rd }}$ Ed. New York: McGraw-Hill 2010;706-56.

5. Sibai, Dekkar G, Kupferminc M. Preeclampsia. Lancet. 2005;365(9461):785-99.

6. Duha D, Konar H. Textbook of Obstetrics Including Perinatology and Contraception. $5^{\text {th }}$ ed. Culcutta: New Central Book Agency (p) ltd. 2001;234-55.

7. Bellamy L, Casas JP, Hingorani AD, Williams DJ. Preeclampsia and Risk of Cardiovascular Disease and Cancer in Later Life: Systematic Review and Metaanalysis. Obstet Anesth Digest. 2008;28(2):80.
8. Soloman CG, Seely EW. Preeclampsia-Searching for the cause. N Eng J Med. 2004;350(7):641-12.

9. Irgens HU, Roberts JM, Reisæter L, Irgens LM, Lie RT. Long term mortality of mothers and fathers after preeclampsia: population based cohort study Pre-eclampsia and cardiovascular disease later in life: who is at risk? BMJ. 2001;323(7323):1213-7.

10. Bonnar J, Mcnicol GP, Douglas AS. Mean platelet and red cell volume measurement to estimate the severity of hypertension in pregnancy. Br. M Journal. 1971;2:12.

11. Shehata N, Burrows R, Kelton JG. Gestational thrombocytopenia. Clin Obstet Gynecol. 1999;42:32734.

12. Redman CWG, Bonnar J, Beilin L. Early platelet consumption in preeclampsia. BMJ. 1978;1:467-9.

13. Sibai BM, Caritis S, Hauth J. What we have learned about preeclampsia. Semin Perinatol. 2003;27(3):23946.

14. Lindheimer MD, Taler SJ, Cunningham FG. Hypertension in pregnancy. J Am Soc Hypertens. 2008;2(6):484-94.

15. American College of Obstetricians and Gynecologists (ACOG) Practice bulletin: Diagnosis and management of preeclampsia and eclampsia. Obstet Gynecol. 2002;99(1):159-67.

16. Rath W, Fischer T. The diagnosis and treatment of hypertensive disorders of pregnancy: New findings for the antenatal and inpatient care. Dtsch Arztebl Int. 2009;106(45):733-8.

17. Hasanzadeh M, Ayatollahi H, Farzadnia M, Ayati S, Khoob MK. Elevated plasma total homocysteine in preeclampsia. Saudi Med J. 2008;29:875-8.

18. Vahidroudsari F, Ayati S, Torabizadeh A, Ayatollahi H, Esmaeli H, Shahabian M. Serum calcium and magnesium concentration in preeclamptic and normal pregnancies; a comparative study. J Reprod Infertil. 2008;9:256-62.

19. Hladunewich M, Karumanchi SA, Lafayette R. Pathophysiology of the clinical manifestations of preeclampsia. Clin J Am Soc Nephrol. 2007;2(3):543-9

20. Redman CW, Sargent IL. Latest advances in understanding preeclampsia. Science. 2005;308(5728):1592-4.

21. Beheiry HM, Rayis DR, Elzibair AM, Omer MI, Makwana P, Saeed AM. Evaluation of Serum Cystatin $\mathrm{C}$ as an Indicator of Glomerular Filtration Rate and its Correlations to other Biomarkers in Detection of Preeclampsia. J Afr Ass Physiol. Sci.2015;3(2)199-206.

Cite this article as: Beheiry HM, Ali IA, Abdalla MS, Sharif AM, Saeed AM. Correlations of complete blood count, liver enzyme and serum uric Acid in Sudanese pre-eclamptic cases. Int J Reprod Contracept Obstet Gynecol 2018;7:1308-12. 